\title{
Two Recent Radiation-Related Genetic False Alarms: Leukemia in West Cumbria, E ngland, and Minisatellite Mutations in Belarus
}

\author{
J AME S V. NE E L* \\ Department of Human Genetics, University of Michigan, Ann Arbor, Michigan 48109-0618
}

\begin{abstract}
Within the past decade, two reports have appeared purporting to demonstrate much greater human sensitivities to the genetic effects of radiation than are consistent with the J apanese or mouse data that I summarized earlier in this program. This presentation will review these reports, both of which are badly flawed, and then proceed to a few poignant remarks concerning the responsibilities of scientists, scientific journals, and even the press, with respect to highly sensitive genetic topics.
\end{abstract}

\section{CHILDHOOD LEUKEMIA IN WEST CUMBRIA, ENGLAND}

In 1983, Yorkshire Television drew attention to an apparent excess of childhood leukemia in the vicinity of the Sellafield Nuclear Reprocessing Plant, which is located in West Cumbria, England. The presentation was sufficiently compelling that the English Government commissioned a survey by an Independent Advisory Group, which confirmed that there was indeed an excess (Black, '84; Gardner et al., '87a,b), and Martin Gardner and associates were then requested to undertake a study of associated risk factors, with particular reference to factors related to the plant. The subjects were 52 persons with leukemia, 22 with non-Hodgkin's Iymphoma, and 23 with Hodgkin's disease, all with onset in people born in the area between 1950 and 1983, with diagnosis under the age of 25, and 1,001 controls matched for sex and age taken from the same birth registers as the cases (Gardner et al., '90a,b). Associations were sought with such factors as place of residence, viral infections, child's play habits, and parental occupational histories. Some 80 possible associations were investigated. (This number in itself immediately raises the possibility of several "statistically significant" false-positive associations simply on the basis of the number of tests performed.) The principal positive finding was that relative risks of leukemia and nonHodgkin's Iymphoma were higher in children born near Sellafield and in children of father's employed at the plant. For example, the relative risk was 2.4 (95\% confidence interval [C.I.] of 1.0-5.7) for children of fathers employed at Sellafield at the time of their conception, and 6.4 (C.I. 1.67-26.3) for children of fathers receiving a total preconceptual (external badgerecorded) dose of ionizing radiation of more than 100-
mSv equivalents (but there were no exposures exceeding approximately 200-mSv equivalents). The authors focused special attention on the village of Seascale, 3 $\mathrm{km}$ south of Sellafield, where a clustering of cases had been observed. Altogether seven cases had been diagnosed in residents of the village less than 25 years of age in the 29 years 1955-1983, five of which were in children less than 10 years of age, when less than one case at these ages (actually, 0.5 cases) would have been expected at national rates. Four of the fathers of the affected children were employed in the Sellafield plant (expectation, 0.6; relative risk, 6.4), where they had received estimated total preconceptual (badge) doses of ionizing radiation ranging from 97 to 188 mSv equivalents over a period of 6-13 years. The authors concluded that: "This result suggests an effect of ionizing radiation on fathers that may be leukaemogenic in their offspring, though other, less likely, explanations are possible."That they beli eve this effect was genetic is indicated by their comparison of their findings with other, avowedly genetic studies. The sensitivity of the human genome to the genetic effects of ionizing radiation implied by this interpretation is, of course, far, far in excess of current estimates.

Understandably, the publication of these findings in the British Medical J ournal in February of 1990 elicited a flurry of comments, some incredulous, some hailing a new major insight into radiation effects. A British law firm, Leigh, Day, and Company, advertised its willingness to file claims against the organization operating the facility, British Nuclear Fuel plc (BNFL), and relatives of two of the children soon initiated action against BNFL, claiming damage for personal injuries and, in one of the two cases, death. A finding for the Plaintiffs would challenge, worldwide, present permissible occupational exposures to ionizing radiation, as well as the validity of the major corpus of experimental data from the mouse, and the observational data from J apan on the children of atomic bomb survivors. Such a finding would also trigger a flood of similar legal actions. The stakes were high. So was the cost: The London Times has estimated (October 15, 1992) that

*Correspondence to: J ames V. Neel, Department of Human Genetics, Box 0618, M4708 Medical Science II, University of Michigan, Ann Arbor, MI 48109-0618. 
the resulting procedures, before the Royal High Courts of J ustice of England, are expected "to be a record breaking legal action, costing up to $f 10$ million." (The expenses of both plaintiffs and defendant will ultimately be met by the government.)

Concerning the reliability of the findings of Gardner and associates, there can be little doubt. A parallel study by McKinney and associates ('91) on parental occupations of children with leukemia in West Cumbria, North Humberside, and Gateshead, all areas in which high rates of childhood leukemia had previously been documented, confirmed the finding of the Gardner group in West Cumbria, not surprising in view of the overlap in subjects. But McKinney et al. ('91) also reported significant associations of childhood leukemia with the preconceptional exposure of fathers to wood dust and benzene. The significance of these latter two findings must be viewed in light of the fact that by the authors' estimate, 480 comparisons were made. It is noteworthy that this study failed to confirm previously reported associations of childhood leukemia with parental exposure to pesticides, plastics, and paint and pigments-but these facts did not find their way into the abstract of the McKinney paper, let al one inspire a press release! Draper et al. ('93) several years later also confirmed the excess of leukemia in the Seascale area, and added additional data for 1984-1990, finding for the latter period that "the incidence of malignant disease, particularly lymphoid leukemia and nonHodgkin's Iymphomas in young people aged 0-24 in Seascale was higher than would be expected."

\section{The Legal Action Unfolds}

The trial that resulted was conducted by a single judge in the Royal High Courts of J ustice in London. During the course of the trial, there were approximately a dozen-plus expert witnesses on both sides, of whom J ack Schull and I were two. What I think impressed both of us were the academic-type witnesses for the plaintiffs who either said, "we know so little about radiation effects that the Sellafield findings could indeed be a radiation effect," or who sought to discredit the J apanese study for various, sometimes arcane reasons, none of which, fortunately, seem to have impressed the judge.

At the end of the day, the evidence that led to the judge finding against the plaintiffs was of two types, biol ogical and epidemiol ogi cal. What follows is a condensation of a more extensive analysis presented elsewhere (Neel, '94; see al so Doll et al., '94; Little et al., '95; Tawn, '95; Wakeford, '95). The principal issues raised by the study can be summarized under four headings:

1. At the phenomenological level, there was a flat contradiction between the failure to detect an increase in childhood leukemia in the extensive studies on malignancies in the children of a-bomb survivors (Yoshimoto et al., '90, '91) and the observations regarding leukemia in Sellafield.
2. Earlier in this Symposium, it was suggested that the zygotic doubling dose for humans of acute ionizing radiation was of the order of $2 \mathrm{~Sv}$ equivalents. We have al so suggested that for chronic radiation exposures, such as were experienced in the Sellafield plant, the doubling dose could to a first approximation be set at 4-Sv equivalents (Neel et al., '90). Let us assume that childhood leukemia is the result of a single dominant mutation (patently untrue; see below). Then, assuming that a cumulative dose of approximately $150 \mathrm{mSv}$ to the Sellafield workers resulted in a relative risk of 6.4 for leukemia in their children, the doubling dose would become about 25 $\mathrm{mSv}$, some 160 times lower than the estimate of the doubling dose of chronic radiation developed earlier. Little ('90), employing a somewhat different approach, places the discrepancy at 50 - to 80 -fold. However, childhood leukemia is not based on a single dominant mutation as is implied in that comparison. It is not in a class with retinoblastoma, neuroblastoma, or Wilms' tumor, these the more "genetic" of the childhood malignancies. On the basis of present evidence, not more than $5 \%$ of childhood leukemia can be attributed to a genetic basis of the type that accounts for familial retinoblastoma. This is the fraction which should be responsive to a radiation-induced mutation in the appropriate gene in a parent. The fact that the Sellafield doses which are reported are badge, not gonad, doses should introduce another factor of $\sim 1 / 2$ into a comparison of the Sellafield data. If we combine these various considerations, the discrepancy between the results of the Sellafield and J apanese studies is easily several thousandfold.

3. Earlier in this Symposium, we briefly considered the matter of the doubling dose for mice. If for the moment you accept the zygotic doubling dose for the acute radiation of mice of $2.7 \mathrm{~Gy}$ as the best currently available, adjust by a factor of 3 upward for the fact that the radiation at Sellafield was chronic in nature (cf. Russell, '63), the discrepancy between the mouse data and the genetic interpretation of the Sellafield findings is even greater than with the human data.

4. The Sellafield findings would require a remarkable specificity for the genetic effects of radiation, which effects are currently viewed as shotgun in nature. Thus, if these findings were a genetic phenomenon, there should have been a spectacular increase in the frequency of other genetic disease resulting from new mutations in the area covered by the Gardner studies. However, J ones and Wheater ('89) reported no increase in congenital defects in children born at West Cumberland Hospital, which services the area covered by the Gardner studies.

These, then, are the principal reasons for questioning at the time of publication the validity of the conclusions of Gardner and associates concerning the cause of the 
cluster of childhood leukemia in Seascale. However, as time went along, a new set of epidemiological concerns materialized. Not surprisingly, the Gardner report set off a series of studies attempting confirmation. Three independent studies of the association of childhood leukemia with paternal employment in a nuclear instalIation failed to confirm the Gardner report (Kinlen, '93; Kinlen et al., '93; McLaughlin et al., '92; Roman et al., '93). F urthermore, the town of Seascale is only one of several towns in the vicinity of the Sellafield plant in which workers at the plant reside. A study of these other areas yielded no evidence for an increase in childhood leukemia correlated with paternal employment at the plant (Craft et al., '93; Parker et al., '93).

After some 8 months of intermittent testimony, the judge deliberated for 4 months, and then issued such a strong verdict in favor of the defendant, British Nuclear Fuel, plc, that there has been no appeal. A verdict for the plaintiff would, of course, have forced a reappraisal of the radiation protection standards of all manner of agencies, including this one. Before, however, you issue a collective sigh of relief, I should tell you that a new suit is brewing, involving attribution of a cluster of children with Down's syndrome in Ireland, in a locale just across the Irish Sea from the Sellafield plant, to maternal exposure to radioactive contamination from the plant.

\section{MINISATE LLITE MUTATIONS IN BELARUS}

I nasmuch as the genetic effects to be expected at the levels of increased radiation to which human populations may be exposed are small, a proper genetic study of the effects of a radiation exposure upon a population demands impeccable controls. In such a situation, it is tempting to look for a shortcut, some kind of easily applied litmus paper test. That is exactly the trap into which Dubrova and colleagues seem to have fallen in their report in Nature (April 25, 1996). Studying germline mutation rates in human minisatellite loci in the Chernobyl fallout contaminated areas of the Mogilev district of Belarus and in a control population, they report that: "The frequency of mutation was found to be twice as high in the exposed families as in the control group." Because both parents were exposed, this is a zygotic rate. Minisatellites are regions of the DNA characterized by a variable number of tandem repeats of, usually, 5-45 bp identical units. They are relatively common in the genome, and well known to exhibit a high rate of spontaneous mutation, mutation in this case consisting primarily in the gain or loss of one or several of these repeat units. The mechanisms responsible for these mutations are not well understood. These mutations are not accompanied by any detectable phenotypic effect, i.e., appear to be of no consequence to the person to whom they are transmitted. This report, in a highly respected journal, can only bring great and unwarranted distress to an already badly stressed population. There are at least six rea- sons why that report must be viewed with great caution:

1. Choice of controls: The control group of parents and children were drawn from the United Kingdom. This is a violation of one of the first principles of genetic epidemiology, since these controls are neither matched by environment nor by ethnicity. With respect to the former, Belarus and surrounding regions are known to be subject to a high level of industrial pollution. With respect to thelatter, strain differences in mutation rates are very well known in mice and Drosophila, and, especially for such labile markers as minisatellites, certainly cannot be excluded for the human species.

2. Dosimetry: Dosage reconstruction for this area presents many difficulties (Balonov, '96). The principal source of radiation is ${ }^{137} \mathrm{Cs}$; the authors estimate from various sources that the average individual dose for external and internal chronic exposure to this element was "less than 5 mSv per year." Since the children studied were born in 1994, both their parents had been exposed to this dose for approximately 8 years, for a combined total maximum dose of $8 \times 2 \times 5=80 \mathrm{mSv}$ (or 8 rem) of chronic radiation, and the average may be one-half of that! However, what is important is the gonad dose, and this is probably less than half the external dose. So, the study is reporting an effect of gonadal doses of radiation only a few rem above background.

3. Lack of perspective: Given the available estimates of the doubling dose of chronic radiation for mice and humans, their finding suggests sensitivities some 200 times greater than the literature. The authors recognize the discrepancy and invoke the induction by the radiation of some unknown intermediary mechanism which then causes the mutation. Since the basis for the gain or loss of repeat units which they are measuring in these minisatellites is unclear, it is difficult to discuss this suggestion critically, but it is difficult to imagine a "special mechanism" specific for this type of mutation that has not previously come to light.

4. Treatment of results from J apan: At the time the authors submitted their paper to Nature, they were unaware of a comparable study at the RERF. This is understandable, since the results of the study in J apan were published in December 1995, and the Naturepaper appeared in April, 1996. The J apanese study did, however, cometo their attention in timeto add a note in proof, namely, "A similar study of minisatellite mutation in a relatively small number of families of atomic-bomb survivors from Hiroshima and Nagasaki has failed to show evidence for mutation induction following acute exposure." This is a quite misleading statement. The average gonadal dose of the parents of the $64 \mathrm{~J}$ apanese children who were studied was 1.9-Sv equivalents, so that the total dose represented by these children 
was $64 \times 1.9=121.6 \mathrm{~Sv}$ equivalents of acute radiation. The exposure of the parents of the Belarus children was $\sim 7.5$ years $\times 5 \mathrm{mSv} /$ year $\times 2$ parents $\times 79$ children $=5.9 \mathrm{~Sv}$ equivalents of chronic radiation. Acute exposures to ionizing radiation, as in J apan, are commonly held to be some two to three times as effective in inducing mutation as chronic exposures, as in Byelorussia. Therefore, the J apanese study should have $(121.6 \times 3) / 5.9=62$ times the power of the Byelorussian study. Mohrenweiser (unpublished observations) in a preliminary study also finds no effect of parental radiation on the rate of minisatellite mutations, in studies of the children of the so-called Chernobyl liquidators, for whom the radiation dose was substantially higher than for the parents reported by Dubrova et al. ('96). It is noteworthy that for both the Mohrenweiser study and that of Kodaira et al. ('95), the data are counterhypothesis, so that it is unlikely any expansion of either series will produce a statistically significant effect of the exposures.

5. Failure to discuss the discrepancy with the experimental mouse data on the same subject: In support of the validity of their finding, Dubrova et al. ('96) cite two experiments demonstrating the production of minisatellite mutations in mouse spermatogonia by gamma radiation. In the first of these (Dubrova et al., '93), the gametic doubling dose was approximately $1.4 \mathrm{~Gy}$, whereas in the second (Sadamoto et al., '94), the gametic doubling dose was approximately $3.8 \mathrm{~Gy}$. The average is $2.6 \mathrm{~Gy}$, the male gametic rate, or, to a first approximation, a zygotic rate of $5.2 \mathrm{~Gy}$ acute radiation, if we assume the same response in the female. If we use the customary factor of 3 in extrapolating from the effects of acute to chronic radiation at the mouse exposure levels, this estimate becomes $15.6 \mathrm{~Gy}$. Thus, the human data from Belarus suggest a sensitivity that is 195 times greater than the experimental results with mice!

6. Choice of indicator: Finally, we must consider the choice of the DNA indicator for this study. Certainly a variety of types of DNA should be examined if studies of the genetic effects of radiation move to the DNA level. The choice of minisatellites was perhaps dictated by their relatively high spontaneous rate, and the thought that they might be an unusually sensitive indicator of radiation effects. In my view, however, we should not be concentrating on presumably sensitive indicators, especially of unknown function, but on a representative battery, of which this might be only one.

In summary, there are many reasons to be skeptical of the conclusions of Dubrova et al. ('96; see also Léonard and Gerber, '96). These authors, having raised the issue, should be strongly encouraged to do a properly controlled study. Such a study, together with an extension of the study of Kodaira et al. ('95) and of
Mohrenweiser (personal communication) should put the matter to rest.

In closing, let us turn to the more general issue of scientific responsibility. We live in an age of apprehension, and, indeed, there is much to be apprehensive about as we attempt to look into the future. Stories about genetic risks, playing on parental concerns for their children, in particular create anxieties. It is, therefore, essential and appropriate to conduct careful and appropriate evaluations of each perceived threat as it emerges, as well as continuing cost-benefit analyses on established exposures, such as radiation. But those conducting these eval uations carry heavy social responsibilities. We have just considered two studies, one certainly, and the other probably, unrepeatable. The first sparked both widespread concern and a very expensive chain of events, the other certainly contributed to the current great angst of those exposed to the fallout from the Chernobyl disaster.

Elsewhere I have argued that by now the scientific community should have acquired sufficient sophistication in epidemiological matters that when the results of a study are at marked variance with a large body of other data, the authors make it very clear how far out of line their results are; that scientific journals that sometimes seem as much in pursuit of hot items as the tabloids, be more critical; and that science writers, faced with an "astounding" development, exercise a very high level of skepticism (Neel, '94). It seems strange that thejournal Naturedid not hold up publication of the paper by Dubrova et al. ('96), when, just before publication, it learned of the negative study by Kodaira et al. ('95). Whether bodies such as the NCRPM have an expanded role to play in these situations is a subject we might well discuss.

\section{LITERATURE CITED}

Balonov MI. 1996. Chernobyl dosefor population of areas radiocontaminated after the Chernobyl accident. In: Till J E, editor. Environmental dose reconstruction and risk implications. Washington, DC: National Council on Radiation Protection and Measurements. $p$ 207-243.

Craft AW, Parker L, Openshaw S, Charlton M, Newell J , Birch J , Blair V. 1993. Cancer in young people in the north of England, 1968-1985: Analysis by census wards. J Epidemiol Community Health 47:109115.

Doll R, Evans HJ , Darby SC. 1994. Paternal exposure not to blame. Nature 367:678-680.

Draper GJ , Stiller CA, Cartwright RA, Craft AW, Vincent TJ . 1993. Cancer in Cumbria and in the vicinity of the Sellafield nuclear installation, 1963-1990. BMJ 306:89-94.

Dubrova YE, J effreys AJ , Malashenko AM. 1993. Mouse minisatellite mutations induced by ionizing radiation. Nature Genet 5:92-94.

Dubrova YE, Nesterov VN, Krouchinsky NG, Ostapenko VA, Neumann R, Neil DL, J effreys AJ . 1996. Human minisatellite mutation rate after the Chernobyl accident. Nature 380:683-686.

Gardner MJ , Hall AJ , Downes S, Terrell J D. 1987a. Follow up study of children born elsewhere but attending schools in Seascale, West Cumbria (schools cohort). BMJ 295:819-822.

Gardner MJ , Hall AJ , Downes S, Terrell J D. 1987b. Follow up study of children born to mothers resident in Seascale, West Cumbria (birth cohort). BMJ 295:822-827. 
306

J .V. NEEL

Gardner MJ, Snee MP, Hall AJ, Powell CA, Downes S, Terrell J D. 1990a. Results of case-control study of leukaemia and Iymphoma among young people near Sellafield nuclear plant in West Cumbria. BMJ 300:423-429.

Gardner MJ, Hall AJ , Snee MP, Downes S, Powell CA, Terrell J D. 1990b. Methods and basic data of case-control study of leukaemia and lymphoma among young people near Sellafield nuclear plant in West Cumbria. BMJ 300:429-434.

J ones KP, Wheater AW. 1989. Obstetric outcomes in West Cumberland Hospital: Is there a risk from Sellafield?J R Soc Med 82:524-527.

Kinlen LJ . 1993. Can paternal preconceptual radiation account for the increase of leukaemia and non-Hodgkin's lymphoma in Seascale? BMJ 306:1718-1721.

Kinlen LJ , Clarke K, Balkwill A. 1993. Paternal preconceptual radiation exposure in the nuclear industry and leukaemia and nonHodgkin's lymphoma in young people in Scotland. BMJ 306:11531158.

Kodaira M, Satoh C, Hiyama K, Toyama K. 1995. Lack of effects of atomic bomb radiation on genetic instability of tandem-repetitive elements in human germ cells. AmJ Hum Genet 57:1275-1283.

Léonard A, Gerber GB. 1996. Does the Chernobyl accident increase genetic defects in exposed human populations? Scope-Radtest N ewsl 11:4-6.

Little MP. 1990. A comparison between the risks of childhood leukae mia from parental exposure to radiation in the Sellafield workforce and those displayed among the J apanese bomb survivors. J Radiol Prot 10:185-198.

Little MP, Charles MW, Wakeford R. 1995. A review of the risks of leukemia in relation to parental pre-conception exposure to radiation. Health Phys 68:299-310.

McKinney PA, Alexander FE, Cartwright RA, Parker L. 1991. Paren- tal occupations of children with leukaemia in west Cumbria, North Humberside, and Gateshead. BMJ 302:681-687.

Neel J V. 1994. Problem of "false positive" conclusions in genetic epidemiology: Lessons from the leukemia cluster near the Sellafield nuclear installation. Genet E pidemiol 11:213-233.

Neel J V, Schull WJ , Awa AA, Satoh C, Kato H, Otake M, Yoshimoto Y. 1990. The children of parents exposed to atomic bombs: Estimates of the genetic doubling dose of radiation for humans. Am J Hum Genet 46:1053-1072.

Parker L, Craft AW, Smith J, Dickinson H, Wakeford R, Binks K, McElvenny D, Scott L, Slovak A. 1993. Geographical distribution of preconceptional radiation doses to fathers employed at the Sellafield nuclear installation, West Cumbria. BMJ 307:966-971.

Roman E, Watson A, Beral V, Buckle S, Bull D, Baker K, Ryder H, Barton C. 1993. Case-control study of leukaemia and non-Hodgkin's lymphoma among children aged 0-4 years living in West Berkshire and North Hampshire health districts. BMJ 306:615-621.

Russell WL. 1963. The effect of radiation dose rate and fractionation on mutation in mice. In: Sobels F, editor. Repair from genetic radiation. Oxford: Pergamon. p 205-217, 231-235.

Sadamoto S, Suzuki S, Kamiya K, Kominami R, Doh K, Niwa O. 1994. Radiation induction of germline mutation at a hypervariable mouse minisatellitelocus. Int J Radiat Biol 65:549-557.

Tawn EJ . 1995. Leukaemia and Sellafield: Is there a heritable link? J Med Genet 32:251-256.

Wakeford R. 1995. The risk of childhood cancer from intrauterine and preconceptional exposure to ionizing radiation. Environ Health Perspect 103:1018-1025.

Yoshimoto Y, Neel J V, Schull WJ , Kato H, Soda M, Eto R, Mabuchi K. 1990. Malignant tumors during the first 2 decades of life in the offspring of atomic bomb survivors. AmJ Hum Genet 46:1041-1052. 